\title{
Technical note \\ Design of a pot experiment to study the effect of irrigation with diluted winery wastewater on four differently textured soils
}

\author{
AR Mulidzi ${ }^{1 *}$, CE Clarke ${ }^{2}$ and PA Myburgh' \\ 'Soil and Water Science Programme, ARC Infruitec-Nietvoorbij, Private Bag X5026, Stellenbosch 7599, South Africa \\ ${ }^{2}$ Department of Soil Science, University of Stellenbosch, Private Bag X1, Matieland 7602, South Africa
}

\begin{abstract}
Due to the intensification of environmental legislation, the wine industry is expected to find solutions for the treatment or re-use of winery wastewater. The objective of the study was to design and evaluate a pot experiment for determining the effects of irrigation with diluted winery wastewater on different soils. Four pedogenetically different soils were included in the experiment, i.e., (i) alluvial sand containing 3.3\% clay from Rawsonville, (ii) aeolic sand containing $0.4 \%$ clay from Lutzville, (iii) shale-derived soil containing $20 \%$ clay from Stellenbosch, and (iv) granite-derived soil containing $13 \%$ clay from Stellenbosch. The pot experiment was carried out under a rain shelter at ARC Infruitec-Nietvoorbij. Soils were packed in $3.54 \mathrm{dm}^{3}$ PVC pots to a bulk density of $1400 \mathrm{~kg} / \mathrm{m}^{3}$. The four soils were irrigated using winery wastewater that was diluted to $3000 \mathrm{mg} / \mathrm{L}$ COD. Municipal water was used to irrigate the control treatment of each soil. The relatively simple mixing and irrigation infrastructure enabled irrigation of more than one soil with diluted winery wastewater in one experiment. It was possible to irrigate the soils accurately when approx. $85 \%$ of the water had evaporated as no visual drainage occurred. Since the pot experiment could be continued under the rain shelter during winter, results were obtained quicker compared to an open field study. However, weighing the pots every second day was time consuming. Therefore, it is recommended that load cells are to be used to record daily mass losses automatically in future pot experiments.
\end{abstract}

Keywords: bulk density, irrigation system, rain shelter, simulated season, texture

\section{INTRODUCTION}

Increased wine production in South Africa is putting pressure on natural resources such as vegetation, water and soil. This is primarily due to large volumes of wastewater produced during winemaking (Mulidzi et al., 2009). The negative effects of irrigation with winery wastewater on soils are well documented (Bond 1998; Papini, 2000; Mulidzi, 2001; Arienzo et al., 2009; Christen et al., 2010; Laurenson and Houlbrooke, 2011; Laurenson et al., 2012; Mosse et al., 2011; Arienzo et al, 2012). To comply with intensified environmental legislation (Department of Water Affairs, 2013), the wine industry must find solutions for treatment or re-use of winery wastewater (Van Schoor, 2001). Since negative impacts on soils might be less if the winery wastewater is diluted before being re-used for irrigation, such a practice could be more sustainable compared to undiluted wastewater. However, knowledge regarding effects of diluted winery wastewater on different soils in South African grape growing regions is limited.

Determining effects of irrigation with winery wastewater on soils and crops in field experiments requires an elaborate infrastructure, particularly if the wastewater has to be diluted to a predetermined level (Myburgh et al., 2015). Field experiments are usually carried out within one specific soil type. Since different soils respond differently to winery wastewater irrigation (Mulidzi, 2001), it is essential to determine the effects of diluted winery wastewater on soils that differ pedogenically. However, it would be expensive to erect the required infrastructure for a range of soils. A further disadvantage of field

\footnotetext{
To whom all correspondence should be addressed.

e-mail: mulidzir@arc.agric.za

Received: 5 June 2015; accepted in revised form 13 November 2015
}

experiments is that wineries produce the bulk of their wastewater during the harvest period, i.e., from February to April. Therefore, field experiments can only be carried out annually during harvest. Based on the foregoing, pot experiments seem to be an alternative, since these could include a range of different soils. A further advantage is that winery wastewater can be stored in tanks which will allow experiments to be continued throughout the year if the pots are sheltered from rain. This will reduce the duration of experiments compared to ones carried out in the open field. If pot experiments are carried out correctly, drainage and subsequent leaching of elements can be avoided. The latter can be problematic and difficult to quantify under field conditions.

The objective of the study was to design and evaluate a pot experiment to determine the effects of irrigation with diluted winery wastewater on different soils. Effects of irrigation with diluted winery wastewater on the chemical status of the four soils will be presented in subsequent articles.

\section{MATERIALS AND METHODS}

\section{Experiment layout}

Four different soils from grape-growing regions in the Western Cape Province, South Africa, were included in the study. A sandy, alluvial soil was collected in a vineyard near Rawsonville in the Breede River valley. This soil belongs to the Longlands form (Soil Classification Work Group, 1991). A sandy, aeolic soil which belongs to the Garies form was collected near Lutzville in the Lower Olifants River valley. A shale-derived soil was collected on the Nietvoorbij Experimental Farm of the Agricultural Research Council (ARC) near Stellenbosch. A granite-derived soil was also collected at Nietvoorbij. The shale and granite soils belong to the Oakleaf and Cartref forms, 
respectively. For the purposes of this paper, the soils will be referred to as Rawsonville sand, Lutzville sand, Stellenbosch shale and Stellenbosch granite, respectively.

The alluvial sand was collected in a vineyard, whereas the others were from uncultivated land. Composite soil samples were collected from the 0-300 $\mathrm{mm}$ layer at each locality and placed in plastic bags for transport and storage. The shale and granite soils were passed through a $6 \mathrm{~mm}$ mesh sieve to remove large fragments. Triplicate samples were collected from the composited soils for determining particle size distribution at a commercial laboratory (Bemlab, Strand). Five soil particle size classes were determined using the hydrometer method (Van der Watt, 1966). Soil textural classes were assigned according to standard diagrams of the Soil Classification Working Group (1991).

The pot experiment was carried out under a $20 \mathrm{~m} \mathrm{x} 40 \mathrm{~m}$ translucent fibrerglass rain shelter at ARC Infruitec-Nietvoorbij near Stellenbosch. Due to logistical constraints, irrigation water for the control treatments, as well as for wastewater dilution, could not be obtained from Lutzville and Robertson. Therefore, the control treatment soils were irrigated with water supplied by the Stellenbosch municipality. For the wastewater treatments, winery wastewater was diluted to a chemical oxygen demand (COD) level of $3000 \mathrm{mg} / \mathrm{L}$. The undiluted wastewater was collected from the wastewater pit at a winery near Rawsonville, and stored in a $2500 \mathrm{~L}$ plastic stock tank next to the rain shelter. A $500 \mathrm{~L}$ plastic tank was filled with municipal water. The COD in the undiluted wastewater and municipal water was measured using a spectrophotometer (Aqualitic COD-reactor, Dortmund) with appropriate test kits (COD, CSB, 0-15 $000 \mathrm{mg} / \mathrm{L}$ ), as described previously (Myburgh et al., 2015). The COD levels were used to calculate the volumes of winery wastewater and municipal water required to obtain the target COD level. The volume $\left(\mathrm{m}^{3}\right)$ of wastewater required from the stock tank $\left(V_{\mathrm{w}}\right)$ to obtain a certain target COD concentration $\left(\mathrm{COD}_{\mathrm{T}}\right)$ was calculated as follows:

$$
V_{\mathrm{W}}=\left(\mathrm{COD}_{\mathrm{T}}-\mathrm{COD}_{\mathrm{M}}\right) \times V_{\mathrm{T}} /\left(\mathrm{COD}_{\mathrm{S}}-\mathrm{COD}_{\mathrm{m}}\right)
$$

where: $\mathrm{COD}_{\mathrm{m}}$ and $\mathrm{COD}_{\mathrm{s}}$ are the COD concentrations $(\mathrm{mg} / \mathrm{L})$ in the municipal water and the stock tank, respectively, and $V_{\mathrm{T}}$ is the tank volume $\left(\mathrm{m}^{3}\right)$. The volume of wastewater required $\left(V_{\mathrm{w}}\right)$ was pumped from the stock tank into another $500 \mathrm{~L}$ plastic tank where it was mixed with municipal water. The COD in the diluted wastewater was measured while the irrigations were applied.

Treatments were applied over 4 simulated irrigation seasons. Each season consisted of 6 irrigations, which was estimated as the number of irrigations a vineyard would require during the harvest period, i.e., when the highest volumes of wastewater are produced. Hence, a total of 24 irrigations were applied over the 4 simulated irrigation seasons. Each soil/water treatment combination was replicated 3 times in a complete randomised block design. Following each simulated season, i.e., after 6, 12, 18 and 24 irrigations, the soil chemical status was determined to compare the effect of irrigation with diluted winery wastewater to that of municipal water. Since soil sampling was destructive, a replication 'plot' of each soil/water treatment combination consisted of 4 pots (Fig. 1). At the end of each simulated season, one of the four pots was removed for sampling.

\section{Packing of soils to a predetermined bulk density}

The day before the pots were filled, the bulked soils were moistened using municipal water to enhance compaction. Following this, the soils were mixed thoroughly and covered using plastic sheets to minimise water loss. Triplicate soil samples were collected in metal cans to determine the gravimetric water content of the bulked soils. The moist soil samples were weighed and dried in an oven at $105^{\circ} \mathrm{C}$ for $16 \mathrm{~h}$. Samples were removed from the oven and allowed to cool in a desiccator before they were weighed to obtain their oven-dry mass. Gravimetric soil water content $\left(\theta_{\mathrm{m}}\right)$ was calculated as follows:

$$
\theta_{\mathrm{m}}=\left(M_{\mathrm{w}}-M_{\mathrm{d}}\right) \div\left(M_{\mathrm{d}}-M_{\mathrm{c}}\right)
$$

where: $M_{\mathrm{w}}$ is the mass of the moist soil plus the can, $M_{\mathrm{d}}$ is the oven-dry mass of the soil plus the can and $M_{c}$ is the metal can mass. Mass percentage soil water content $\left(\mathrm{SWC}_{\mathrm{m}}\right.$ ) was calculated as follows:

$$
\mathrm{SWC}_{\mathrm{m}}=\theta_{\mathrm{m}} \times 100
$$

All the soils were packed to a bulk density $\left(\rho_{\mathrm{b}}\right)$ of $1400 \mathrm{~kg} /$ $\mathrm{m}^{3}$. The mass of moist soil required to obtain this target $\rho_{\mathrm{b}}$ was calculated as follows:

$$
M_{\mathrm{p}}=\left(\rho_{\mathrm{b}} \times V_{\mathrm{s}}\right) \times\left(1+\mathrm{SWC}_{\mathrm{m}} \div 100\right)
$$

where: $M_{\mathrm{p}}$ is the mass of the moist soil that needs to be packed into the pot $(\mathrm{g}), \rho_{\mathrm{b}}$ is the target bulk density $\left(\mathrm{kg} / \mathrm{m}^{3}\right), V_{\mathrm{s}}$ is the soil volume in $\mathrm{cm}^{3}$. Soils were packed into $3.54 \mathrm{dm}^{3} \mathrm{PVC}$ pots which consisted of $200 \mathrm{~mm}$ lengths of $150 \mathrm{~mm} ø$ PVC pipe with a wall thickness of $4 \mathrm{~mm}$. The base of each pot was machined from a $3 \mathrm{~mm}$ thick PVC sheet, and glued onto one of the open ends. A $10 \mathrm{~mm} \emptyset$ hole was drilled in the bottom of each pot to allow drainage. A piece of $1.5 \mathrm{~mm}$ plastic fly-mesh was placed on the bottom of each pot to prevent the soil from being lost through the drainage hole. All pots were cleaned and weighed before being filled with the soil. A custom-built mechanical press was used to compact the soils to the required $\rho_{\mathrm{b}}$. The packed soil columns were only $190 \mathrm{~mm}$ high, i.e., leaving 10 $\mathrm{mm}$ below the upper edge of a pot free. The surface under the rain shelter was first levelled with a gravel layer to promote even distribution of the irrigation water. A layer of coarse building sand was placed on top of the gravel. The pots were placed onto $240 \mathrm{~mm} \varnothing$ plastic saucers. The area occupied by the pot experiment was $3.7 \mathrm{~m}$ x $7.8 \mathrm{~m}$. For each soil, 4 additional pots were

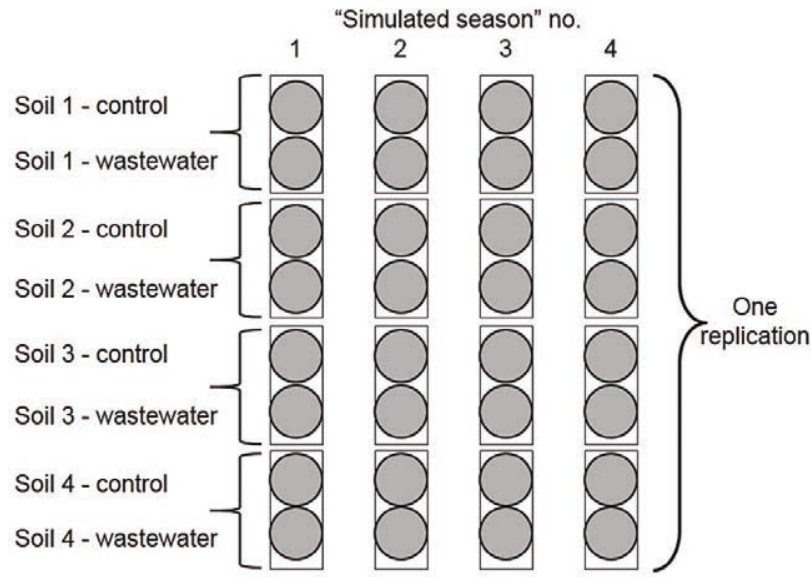

Figure 1

Schematic illustration of the layout of a replication of the treatment pots. In the actual experimental layout, the pots of different treatments were randomised in each replication 
packed. The soil in these pots was saturated using municipal water. After free drainage had stopped, the pots were weighed to obtain the mean mass for each soil at field capacity. The dry soil mass $\left(M_{\text {od }}\right)$ in each pot $(\mathrm{g})$ was calculated as follows:

$$
M_{\text {od }}=V_{\mathrm{s}} \times \rho_{\mathrm{b}}
$$

where: $V_{\mathrm{s}}$ is the volume $\left(\mathrm{dm}^{3}\right)$ of soil and $\rho_{\mathrm{b}}$ is the target bulk density $\left(\mathrm{kg} / \mathrm{m}^{3}\right)$.

\section{Irrigation system}

Two $0.74 \mathrm{~kW}, 3 \mathrm{~m}^{3} / \mathrm{h}$ pumps (Foras, Berg River Irrigation, Paarl) were used to apply the municipal and diluted winery wastewater to the respective soil/water treatment combinations. The municipal and diluted winery wastewater passed through two $130 \mu \mathrm{m}$ ring filters (Arkal, Netafim, Kraaifontein) installed downstream of each pump. An 8-way manifold with a ball valve at each outlet allowed individual irrigation of 8 soil/ water treatment combinations. Water was distributed through a network consisting of $17 \mathrm{~mm} ø$ laterals, and applied to each pot by means of a $2 \mathrm{~L} / \mathrm{h}$ pressure compensating button dripper with a 4-way manifold attached to it (Netafim, Kraaifontein). Four $700 \mathrm{~mm}$ long, $3 \mathrm{~mm}$ inner $ø$ micro-tubes were attached to each dripper manifold (Fig. 2). In order to obtain equal flow through the four micro-tubes, an inline labyrinth-type dripper (Arrow, Netafim, Kraaifontein) was inserted in the open end of each micro-tube to create some back pressure. To distribute the irrigation water uniformly over the soil surface, the four microtubes were supported by a brace placed onto each pot (Fig. 3). The brace, in the form of a cross, was made from two $1.8 \mathrm{~mm}$ x $7 \mathrm{~mm}$ x $205 \mathrm{~mm}$ galvanised metal strips. On each side of the metal strips, the last $20 \mathrm{~mm}$ was bent at a rectangle so that the brace fitted firmly onto a pot. The four micro-tubes were pushed through $5 \mathrm{~mm} ø$ holes drilled in the brace. The flow rate through each of the four micro-tubes was $0.5 \mathrm{~L} / \mathrm{h}$. The total flow rate through the four micro-tubes $\left(Q_{\text {drip }}\right)$ was $34 \mathrm{~mL} / \mathrm{min}$.

\section{Irrigation volumes}

The volume of water applied to each soil was recorded using water meters. The mass of water in each soil at field capacity $\left(W M_{\mathrm{fc}}\right)$ was calculated as follows:

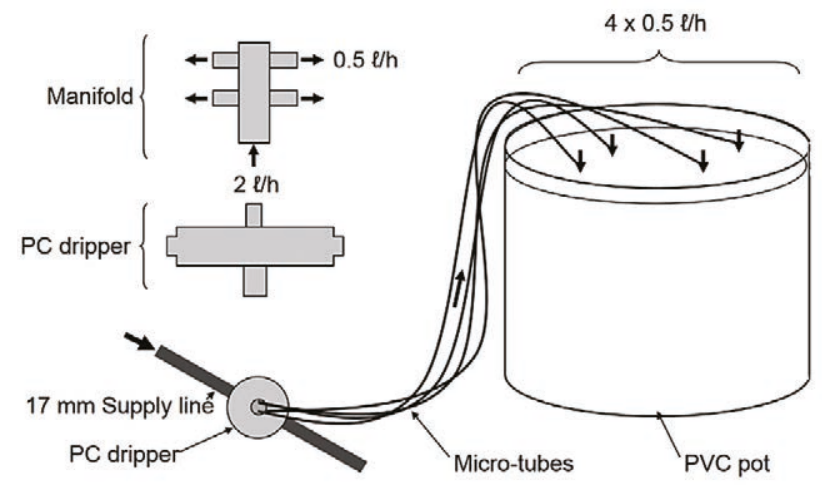

Figure 2

Schematic illustration of the configuration of the pressure-compensating $(P C)$ dripper, manifold and micro-tubes to distribute water evenly in the pots

$$
W M_{\mathrm{fc}}=M_{\mathrm{fc}}-M_{\mathrm{od}}
$$

where: $M_{\mathrm{fc}}$ is the mean pot plus soil mass at field capacity (g) and $M_{\text {od }}$ is the pot plus oven-dry soil mass ( $\mathrm{g}$ ). To irrigate when $W M_{\mathrm{fc}}$ had evaporated to a specific depletion percentage $(P)$, the pot plus soil mass at that depletion percentage $\left(M_{\text {depl }}\right)$ was calculated as follows:

$$
M_{\mathrm{depl}}=M_{\mathrm{od}}+\left(W M_{\mathrm{fc}} \times P \div 100\right)
$$

Since weighing 96 pots was too laborious, only 4 representative pots per soil/water treatment, i.e., 32 in total, were weighed. Before weighing these pots, the braces bearing the micro-tubes were removed. An electronic balance was used to weigh the pots every second day until the mass reached $M_{\text {depl }}$. Assuming that the water density is $1 \mathrm{~g} / \mathrm{cm}^{3}$, the irrigation volume required per pot was calculated as follows:

$$
V_{\text {irr }}=W M_{\mathrm{fc}}-M_{\mathrm{act}}
$$

where $V_{\text {irr }}$ is the volume of water required per pot $(\mathrm{mL})$ and $M_{\text {act }}$ is the actual pot plus soil mass before irrigation (g). The time required to apply $V_{\mathrm{p}}$ was calculated as follows:

$$
t=V_{\text {irr }} \div Q_{\text {drip }}
$$

where $t$ is the time (min) and $Q_{\text {drip }}$ is the total flow rate through the four micro-tubes $(\mathrm{mL} / \mathrm{min})$. The soils were irrigated when their $P$ reached approx. $85 \%$. This high level of depletion was to ensure adequate soil aeration between irrigations. When pots were removed for soil chemical analyses, their irrigation water was collected in $500 \mathrm{~mL}$ glass beakers and discarded. This was to maintain the same irrigation system flow rate throughout the experiment.

\section{RESULTS AND DISCUSSION}

Since only topsoil was used in the study, characteristics of the deeper horizons were considered to be irrelevant. With the exception of the Stellenbosch granite soil, which had a high coarse sand fraction, fine sand dominated the sand fraction (Table 1). According to Van Huyssteen (1989), this particular soil contains approx. $47 \%$ gravel, i.e., $2-6 \mathrm{~mm} \emptyset$, in its natural state. All soils compacted with relative ease to a $\rho_{\mathrm{b}}$ of 1400 $\mathrm{kg} / \mathrm{m}^{3}$. When the soils were packed into the pots, mean water contents were $14.9 \%, 11.7 \%, 12.1 \%$ and $14.5 \%$, respectively, for the Rawsonville sand, Lutzville sand, Stellenbosch shale soil and Stellenbosch granite soil. Irrigation amounts applied to

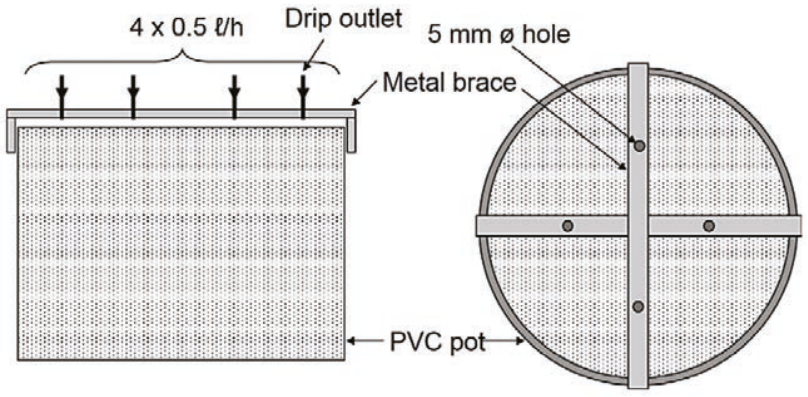

Figure 3

Schematic illustration of a PVC pot with galvanized metal braces supporting the four micro-tubes 
the Rawsonville sand, Lutzville sand, and Stellenbosch shale soil over the four simulated seasons were comparable, but the Stellenbosch granitic soil received substantially less water (Table 2). As expected, the COD in the municipal water was substantially lower compared to the diluted winery wastewater (Table 3). The COD in the diluted winery wastewater was reasonably close to the target level of $3000 \mathrm{mg} / \mathrm{L}$. Since the COD was comparable between the four simulated seasons (Table 3), it indicated that the chemical status of the water in the tanks remained stable.

The soil water contents at field capacity of the soils were comparable, except for the Stellenbosch granite soil (Fig. 4). This indicated that this particular soil had a lower water-holding capacity compared to the other soils. The lower water-holding capacity of the Stellenbosch granite soil was probably due to the high coarse sand content (Table 1). Initially, the soil water content was restored to field capacity following irrigation in all soils. However, in the case of the Stellenbosch granite, field capacity was only restored following the first two irrigations (Fig. 4D). From the third irrigation onwards, visual observation revealed that the irrigation water ponded on the soil surface due to poor water infiltration. Consequently, the target soil water depletion level was reached following irrigation, but field capacity could not be restored (Fig. 4D). Although actual soil water content was not measured in the pots, it can be assumed that only the upper section of the profile in the Stellenbosch granite soil was wetted.
Although the level of COD differed substantially between the municipal and winery wastewater (Table 3), water infiltration problems occurred where municipal water, as well as winery wastewater, was applied to the granite soil. The sodium adsorption ratios in the municipal and winery wastewater were $0.8 \pm 0.1$ and $4.6 \pm 0.6$, respectively (Mulidzi and Myburgh, 2014). This confirmed that poor water quality did not cause the problem. Since the soil was not saline, irrigation with low salinity water could not have caused the problem in the case of the clean water treatments. When irrigated with clean river water and a range of diluted winery wastewaters, the near-saturation hydraulic conductivity of this particular soil was considerably lower compared to the other soils, irrespective of the level of water quality (Howell and Myburgh, 2014).

With the exception of the Stellenbosch granite soil, the soil water content was managed between field capacity and the refill point (Fig. 4). This indicated that the soils were well-aerated between irrigations. Since the lower part of the Stellenbosch granite must have remained dry, it implied that this soil was also well-aerated between irrigations. Visual observation revealed that no drainage occurred after irrigations had been applied. Therefore, it can be assumed that no leaching occurred of elements applied via the municipal or diluted winery wastewater. The foregoing indicated that the lysimetric approach provided an accurate measure of the irrigation volumes required. It is important to note that the pot experiment was completed in approximately 2.5 years, whereas it would have taken 4 years to do the wastewater irrigations in a field experiment.

TABLE 1

Locality, soil form, particle size distribution $(\leq 2 \mathrm{~mm})$ and textural class for the $\mathbf{4}$ soils included in the study

\begin{tabular}{|c|c|c|c|c|}
\hline & Rawsonville sand & Lutzville sand & Stellenbosch shale & Stellenbosch granite \\
\hline Latitude & $-33.693698^{\circ}$ & $-31.558906^{\circ}$ & $-33.911717^{\circ}$ & $-33.917296^{\circ}$ \\
\hline Longitude & $19.322569^{\circ}$ & $18.353115^{\circ}$ & $18.871152^{\circ}$ & $18.864484^{\circ}$ \\
\hline Clay $(<0.002 \mathrm{~mm})$ & 3.3 & 0.4 & 20 & 13 \\
\hline Silt $(0.002-0.02 \mathrm{~mm})$ & 1 & 1 & 13 & 17 \\
\hline Fine sand $(0.02-0.2 \mathrm{~mm})$ & 60 & 69 & 50 & 33 \\
\hline Medium sand $(0.2-0.5 \mathrm{~mm})$ & 29 & 26 & 5 & 3 \\
\hline Coarse sand $(0.5-2 \mathrm{~mm})$ & 8 & 2 & 12 & 35 \\
\hline Soil textural class & Fine sand & Fine sand & Fine sandy clay loam & Coarse sandy loam \\
\hline
\end{tabular}

\begin{tabular}{|l|c|c|c|c|c|}
\hline \multicolumn{7}{c}{ Total irrigation amounts applied to 4 different soils during 4 simulated seasons } \\
\hline \multirow{2}{*}{ Soil } & \multicolumn{3}{|c|}{ Irrigation applied (mm/season) } & \multirow{2}{*}{ Total } \\
\cline { 2 - 7 } & Season 1 & Season 2 & Season 3 & Season 4 & \\
\hline Rawsonville sand & 291 & 289 & 287 & 289 & 1156 \\
\hline Lutzville sand & 281 & 282 & 282 & 281 & 1126 \\
\hline Stellenbosch shale & 246 & 250 & 246 & 245 & 987 \\
\hline Stellenbosch granite & 181 & 180 & 184 & 183 & 728 \\
\hline
\end{tabular}

TABLE 3

Variation in chemical oxygen demand $(\mathrm{mg} / \mathrm{L})$ in the water used for the pot experiment

\begin{tabular}{|l|c|c|c|c|c|}
\hline \multirow{2}{*}{ Water source } & \multicolumn{4}{|c|}{ Season } & \multicolumn{3}{|c|}{ Mean } \\
\cline { 2 - 6 } & $\mathbf{1}$ & $\mathbf{2}$ & $\mathbf{3}$ & $\mathbf{4}$ & 26 \\
\hline Municipal water & 35 & 25 & 3243 & 3190 \\
\hline Diluted winery wastewater & 3149 & 3257 & $3210 \pm 43$ \\
\hline
\end{tabular}



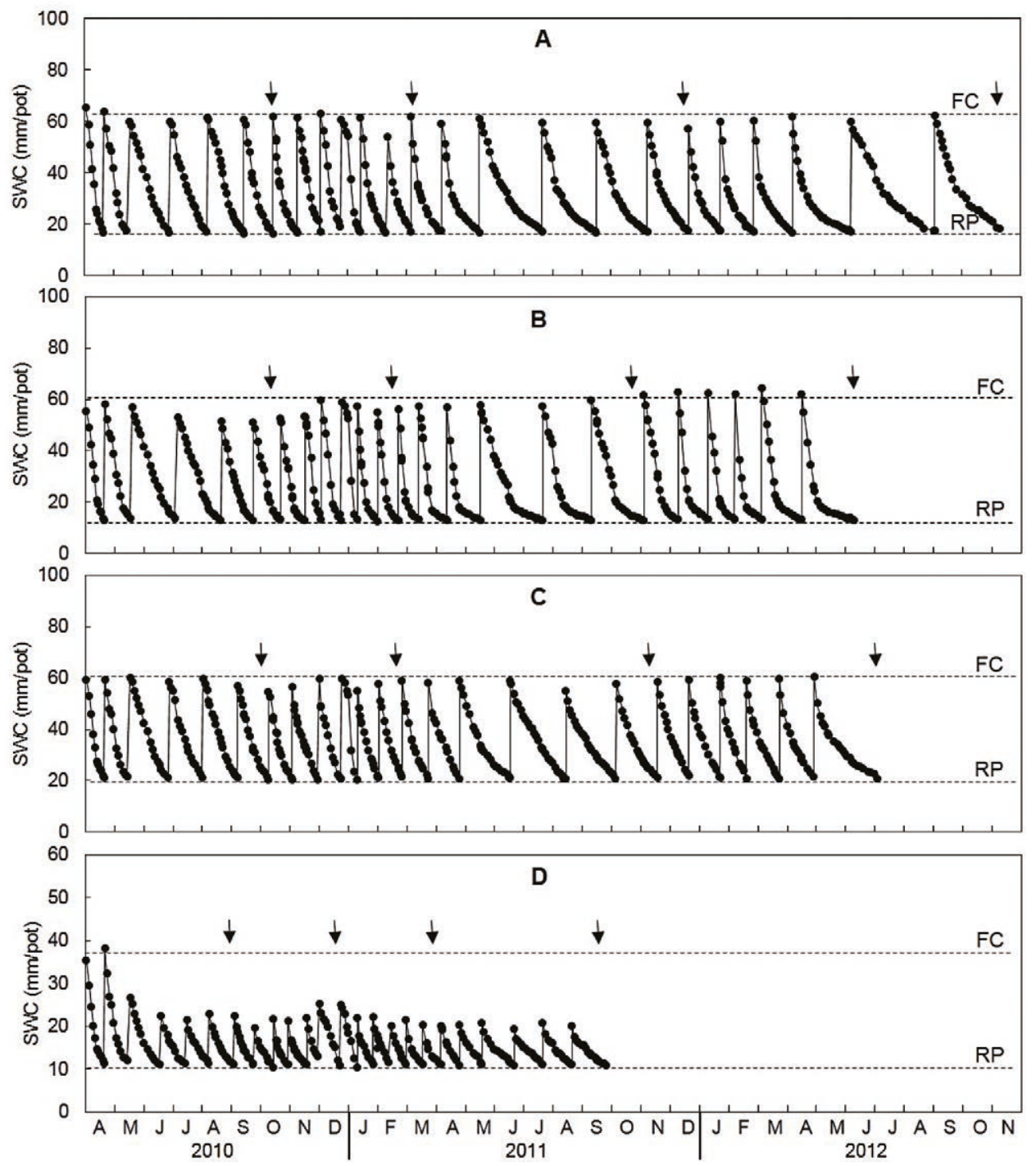

Figure 4

Temporal variation in soil water content (SWC) in (A) Rawsonville sand, (B) Lutzville sand, (C) Stellenbosch shale and (D) Stellenbosch granite soils measured in a pot experiment. Arrows indicate when soil chemical status was determined after each of the simulated seasons. 'FC' and ' $R P^{\prime}$ ' indicate field capacity and refill point, respectively.

\section{CONCLUSIONS}

It was possible to subject more than one soil to irrigation with diluted winery wastewater by using a single mix and irrigation infrastructure. Since the pot experiment could be continued under the rain shelter during winter, results were obtained quicker compared to an open field study. Although only representative pots were weighed, the procedure was still time consuming. Therefore, it is recommended that load cells are used to record daily mass losses automatically. Automatic recording will also be useful for determining mass losses if experiments are carried out with potted plants.

\section{ACKNOWLEDGEMENTS}

The Water Research Commission for initiating and funding the project, as well as Winetech, THRIP (TP1208066038) and ARC Infruitec-Nietvoorbij for co-funding. Staff of the Soil and Water Science programme at ARC Infruitec-Nietvoorbij are thanked for technical support, and in particular Mr Francois Baron for his dedicated effort.

Any opinions, findings and conclusions or recommendations expressed in any publication generated through THRIPsupported research, are those of the author(s) and therefore the NRF/THRIP will not accept any liability in that regard.

\section{REFERENCES}

ARIENZO M, QUAYLE WC, CHRISTEN E and JAYAWARDANE N (2009) Irrigating with winery wastewater? Developing soil stability thresholds and managing total cations. Aust. N.Z. Grapegrow. Winemak. October 2009 86-88.

ARIENZO M, CHRISTEN EW, JAYAWARDANE NS and QUAYLE WC (2012) The relative effects of sodium and potassium on soil hydraulic conductivity and implications for winery wastewater management. Geoderma 173-174 303-310. http://dx.doi. org/10.1016/j.geoderma.2011.12.012

BOND WJ (1998) Effluent irrigation - an environmental challenge for soil science. Aust. J. Soil Res. 36 543-555. http://dx.doi.org/10.1071/ S98017 
CHRISTEN EW, QUAYLE WC, MARCOUX MA, ARIENZO M and JAYAWARDANE NS (2010) Winery wastewater treatment using the land filter technique. J. Environ. Manage. 91 1665-1673. http:// dx.doi.org/10.1016/j.jenvman.2010.03.006

DEPARTMENT OF WATER AFFAIRS (SOUTH AFRICA) (2013) Revision of general authorizations in terms of Section 38 of the National Water Act, 1998 (Act No. 36 of 1998), No. 665. Government Gazette No. 36820, 6 September 2013. Department of Water Affairs, Pretoria.

HOWELL CL and MYBURGH PA (2014) Effect of irrigation with augmented winery wastewater on the hydraulic conductivity of different soils. In: Myburgh PA and Howell CL (eds) The impact of wastewater irrigation by wineries on soil, crop growth and product quality. WRC Report No. 1881/14. Water Research Commission, Pretoria.

LAURENSON S, BOLAN NS, SMITH E and MCCARTHY M (2012) Review: Use of recycled wastewater for irrigating grapevines. Aust. J. Grape Wine Res. 18 1-10. http://dx.doi. org/10.1111/j.1755-0238.2011.00170.x

LAURENSON S and HOULBROOKE D (2011) Winery wastewater irrigation - the effect of sodium and potassium on soil structure. Report prepared for Marlborough District Council. AgResearch Ltd, Invermay, New Zealand.

MOSSE KPM, PATTI AF, CHRISTEN EW and CAVAGNARO TR (2011) Review: Winery wastewater quality and treatment options in Australia. Aust. J. Grape Wine Res. 17 111-122. http://dx.doi. org/10.1111/j.1755-0238.2011.00132.x

MULIDZI AR (2001) Environmental Impact of winery effluent in the Western and Northern Cape Provinces. MSc dissertation, University of Pretoria.
MULIDZI AR, LAKER G, WOOLDRIDGE J and VAN SCHOOR L (2009) Composition of effluents from wineries in the Western and Northern Cape provinces (Part 1): Seasonal variation and differences between wineries. Winetech Technical Yearbook. 58-61. Enartis, Cape Town.

MULIDZI AR and MYBURGH PA (2014) Effect of irrigation with augmented winery wastewater on the chemical properties of four different soils. In: Myburgh PA and Howell CL (eds). The impact of wastewater irrigation by wineries on soil, crop growth and product quality. WRC Report No. 1881/14. Water Research Commission, Pretoria.

MYBURGH PA, LATEGAN EL and HOWELL CL (2015) Infrastructure for irrigation of grapevines with diluted winery wastewater in a field experiment. Water SA 41 643-647. http:// dx.doi.org/10.4314/wsa.v41i5.07

PAPINI AG (2000) Land treatment of grape processing effluents near Robertson, Western Cape. MSc dissertation, University of Cape Town.

SOIL CLASSIFICATION WORK GROUP (1991) Soil Classification - A Taxonomic System for South Africa. Department of Agricultural Development, Pretoria. 257 pp.

VAN HUYSSTEEN L (1989) Quantification of the compaction problem of selected vineyard soils and a critical assessment of methods to predict soil bulk density from soil texture. $\mathrm{PhD}$ thesis, University of Stellenbosch.

VAN DER WATT HVH (1966) Improved tables and a simplified procedure for soil particle size analyses by hydrometer method. S. Afr. J. Agric. Sci. 9 911-916.

VAN SCHOOR LH (2001) A formula for the quantification and prioritization of negative environmental impacts in the wine industry. Wineland May 2001 100-102. 